\title{
Direct Participation in Hostilities and Respect for the Lives of Civilians During Armed Conflicts
}

\section{Introduction}

One of the distinctive characteristics of the contemporary armed conflicts is the proximity of civilians to military operations and their considerable participation in hostilities. Throughout history, civilians have always contributed to the war efforts of the fighting parties, whether through their involvement in arms production, by providing soldiers with food, equipment, shelter or by implementing political objectives closely associated with the military goals. Typically, however, civilians were not present on the battlefield and only a small number of them were actually involved in the conduct of military operations.

In the second half of the 20th century (and in particular in the last decade) and in the first decade of the $21^{\text {st }}$ century situation radically changed -

a continuous shift of the conduct of hostilities into civilian population centres has led to an increased intermingling of civilians with armed actors and has facilitated their involvement in activities more closely related to military operations. Even more recently, the increased outsourcing of traditionally military functions has inserted numerous private contractors, civilian intelligence personnel, and other civilian government employees into the reality of modern armed conflict. ${ }^{2}$

Moreover, in contemporary conflicts states primarily fight wars against non-state armed groups

1 The opinions expressed in this article are those of the author and do not necessarily reflect the views of the Polish Red Cross.

2 International Committee of the Red Cross, 'Interpretive Guidance on the Notion of Direct Participation in Hostilities under International Humanitarian Law' (prepared by N. Melzer), pp. 11-12, at <http://www.icrc.org/eng/resources/documents/publication/p0990.htm>, 2 April 2012. 
to stand a chance against states with superior militaries, these groups often violate international humanitarian law, and more specifically the principle of distinction, by refusing to distinguish themselves from the civilian population. Due to the asymmetry of power, blending in with non-combatants is often a critical part of the non-state armed groups' strategy in places such as Afghanistan, Iraq, the Occupied Palestinian Territories, and Somalia. ${ }^{3}$

As a result, civilians are more likely to fall victim to erroneous or arbitrary targeting, while armed forces - unable to properly identify their adversary - run an increased risk of being attacked by persons they cannot distinguish from the civilian population. ${ }^{4}$

Under such circumstances it is necessary to determine who deserves to be treated as civilian and when such person may become a legitimate target under the law. One of the key elements of the international humanitarian law (hereinafter: IHL) which regulates the conduct of armed conflicts is the principle of distinction between civilians and members of the armed forces/combatants as well as between the civil and military objects/sites (accordingly, the law obliges the parties to an armed conflict to observe this principle). As a consequence, only combatants and military objects may be directly attacked in hostilities. ${ }^{5}$ The above mentioned participation of civilians in various military operations makes it compulsory to provide criteria for distinction between civilians who directly participate in hostilities and the so-called peaceful civilians. It must be clearly emphasized that according to IHL civilians who "take direct part in hostilities" are not protected against attacks and when involved in any such activities may become a legitimate target of attack. In other words, such persons may fall victim and be killed despite the fact that they are civilians. It is therefore of utmost importance to provide a definition of direct participation in hostilities. Will, for instance, acting as human shield, driving vehicles carrying war weapons, operating field computer, providing reconnaissance services or shelter to the armies of the enemy be considered direct participation in hostilities for that purpose?

However, neither Additional Protocols of 1977 to Geneva Conventions, Relating to the Protection of Victims of Armed Conflicts ${ }^{7}$ (nor art. 3 common to Ge-

${ }^{3}$ T.A. Keck, 'Not all civilians are created equal. The principle of distinction, the question of direct participation in hostilities and evolving restraints on the use of force in warfare', Military Law Review, Vol. 211 (2012), p. 115.

4 International Committee of the Red Cross, 'Interpretive Guidance..., p. 12.

${ }^{5}$ See: P. Grzebyk, 'Pojęcia osoba cywilna oraz bezpośredni udzial w dzialaniach zbrojnych (wytyczne Międzynarodowego Komitetu Czerwonego Krzyża', Państwo i Prawo, No. 2 (2012), p. 60 .

${ }^{6}$ Ibid., p. 61. Indeed, "uniform guidelines establishing when and how individuals lose immunity in war are necessary to provide militaries clear targeting guidelines while safeguarding protections for non-combatants". T.A. Keck, 'Not all civilians..., pp. 115-116.

7 See: art. 51 (3) of Protocol Additional to the Geneva Conventions of 12 August 1949, and Relating to the Protection of Victims of International Armed Conflicts, 12 December 1977, 
neva Conventions) provide a clear definition of "direct participation in hostilities" and leave room for doubt and speculations which, in turn, resulted in interpretative abuses to the detriment of IHL principles. Therefore, bearing in mind serious consequences which arise from classifying a civilian as taking direct part in hostilities and for the sake of proper implementation of IHL it is imperative to answer the following three key questions:

1. Who is considered a civilian for the purposes of the principle of distinction?

2. What conduct amounts to direct participation in hostilities?

3. What modalities govern the loss of protection against direct attack?

The attempts were made by the International Committee of Red Cross (ICRC) to clarify those issues, which in 2003 initiated the first, informal meeting of IHL experts relating to armed conflicts. In sum, five expert meetings were held in The Hague and in Geneva between 2003 and $2008 .{ }^{8}$ Based on the discussions held and the research conducted in the course of the expert process, the ICRC drafted its "Interpretive Guidance on the Notion of Direct Participation in Hostilities under IHL" (hereinafter: "Interpretive Guidance"), ${ }^{9}$ which provides the ICRC's recommendations as to how IHL relating to the notion of direct participation in hostilities should be interpreted in light of the circumstances prevailing in contemporary armed conflicts. In doing so, the "Interpretive Guidance" does not endeavour to change or amend existing rules of IHL, but to ensure their coherent interpretation in line with the fundamental principles underlying IHL as a whole. ${ }^{10}$

The present article addresses the notion of direct participation in hostilities in a manner similar to how the problem was handled in "Interpretive Guidance". Therefore, the following questions have been addressed:

1. What is the definition and status of a civilian in time of armed conflict?

2. What conduct amounts to direct participation in hostilities?

1125 UNTS 3 (Additional Protocol I, hereinafter: AP I), and art. 13 (3) of Protocol Additional to the Geneva Conventions of 12 August 1949, and Relating to the Protection of Victims of Non-International Armed Conflicts, 12 December 1977, 1125 UNTS 609 (Additional Protocol II, hereinafter: AP II).

" Each meeting brought together 40 to 50 legal experts from military, governmental and academic circles, as well as from international and non-governmental organizations. The process focused on interpreting the notion of direct participation in hostilities for the purposes of the conduct of hostilities only and did not (or only very marginally) address the legal regime applicable in the event of capture or detention of persons having directly participated in hostilities. N. Melzer, 'The ICRC's Clarification Process on the Notion of Direct Participation in Hostilities under International Humanitarian Law', p. 3, at <http://www.oas.org/dil/esp/XXXVI_curso_The_ICRC_Clarification_Process_Nils_Melzer.pdf >, 2 December 2012.

' This document is available online on the ICRC's website: <http://www.icrc.org/eng/resources/documents/publication/p0990.htm>, 2 December 2012.

I" N. Melzer, 'The ICRC's Clarification..., p. 3. Although the "Interpretive Guidance" is not and cannot be legally binding, in its authors' opinion, the document's conclusions and recommendations may contribute to ensuring that those who do not take a direct part in hostilities receive the humanitarian protection they are entitled to under IHL. Ibid., p. 10. 
3. Should there be any restraints on the use of force against civilians taking direct participation in hostilities and thus being exposed as legitimate targets of attack?

In brief, the legal nature of the principle of distinction has been discussed and the question of temporal loss of protection in case of civilians who are directly involved in military operations is being tackled. The analysis of the above issues is to a certain extent based on arguments presented in "Interpretive Guidance" with the stress being put on those IHL elements that guarantee the respect for the right to life even in circumstances of direct participation in hostilities when civilians may become vulnerable to attacks. Furthermore, like in ICRC document, the phenomenon of "direct participation in hostilities" has been subjected to analysis exclusively from IHL perspective, that is, a set of legal rules which seek, for humanitarian reasons, to limit the effects of armed conflicts. The primary aim of international humanitarian law is to protect the victims of armed conflict (persons who are not, or are no longer, participating in hostilities) and to regulate the conduct of hostilities (to restrict the means and methods of warfare) based on a balance between military necessity and humanity. Admittedly, international law of human rights also applies to armed conflicts but the author, inspired by the approach adopted in "Interpretive Guidance", has decided to reflect upon principles and standards of the above law only indirectly.

Let us underline the fact that the present work focuses only on the issue of the respect of civilians' life in circumstances when they are directly involved in hostilities and are bound to lose protection against "direct attack". It is mandatory to remember that during an armed conflict the life of civilians may be exposed to dangers other than resulting from the direct attack - fatalities among civilians may be caused by other, even non-military activities conducted by the parties to an armed conflict (e.g. individuals condemned to death by the occupational authorities).

\section{The Status of "Civilian" under International Humanitarian Law}

The status and protection from which the civilians benefit during an armed conflict result from the principle of distinction, which is one of the basic principles at the core of IHL. According to Art. 48 of the Additional Protocol I of 1977, "the Parties to the conflict shall at all times distinguish between the civilian population and combatants and between civilian objects and military objectives and accordingly shall direct their operations only against military objectives". Undoubtedly, the principle of distinction also constitutes an integral part of customary international humanitarian law and is recognized as fundamental and intransgressible. As Kenneth Watkin highlights, "distinguishing between combatants and civilians has been, historically and culturally, an important aspect of warfare and has long been recognized as the indispensable means by which humanitarian principles are in- 
jected into the rules governing conduct in war"." Accordingly, the principle of distinction introduces a clear division into combatants and non-combatants (along with military targets and civil objects). IHL identifies no other indirect categories.

Due to the dichotomous classification introduced by the principle of distinction, the concept of a civilian provided by IHL is negatively delimited; therefore civilians are identified as non-combatants. ${ }^{12}$ In particular, according to Art. 50 (1) of AP I, "[a] civilian is any person who does not belong to one of the categories of persons referred to in Article 4 A (1), (2), (3) and (6) of the Third [Geneva] Convention [of 1949] and in Article 43 of this Protocol. In case of doubt whether a person is a civilian, that person shall be considered to be a civilian".

In general, within the group of combatants falls, in a broad sense, the category of members of the armed forces (both regular and irregular) as well as civilian population who took up arms in response to the dangers of invading forces (the so called levée en masse). Combatants are authorized to directly participate in hostilities and therefore may be considered legitimate targets of attacks (unless they surrender or otherwise become hors de combat including due to injuries). ${ }^{13}$ Only combatants are entitled to the prisoner of war status and related privileges because the aforesaid prisoner of war status is the logical consequence of the combatant status. ${ }^{14}$ Non-combatants (civilians), however, may not directly participate

$" \mathrm{~K}$. Watkin, 'Warriors without rights? Combatants, unprivileged belligerents, and the struggle over legitimacy', HPCR Occasional Paper Series, Winter (2005), pp. 8-9. See also: 'Legality of the Threat or Use of Nuclear Weapons', Advisory Opinion of the International Court of Justice, 8 July 1996, ICJ Rep 1996, 226, para 434; J.-M. Henckaerts, L. Doswald-Beck, Customary International Humanitarian Law, t. 1: Rules, Cambridge 2005, rule 1. According to Gary Solis, the principle of distinction is regarded as the "most significant battlefield concept a combatant must observe". G. Solis, The Law of Armed Conflict. International Humanitarian Law in War, New York 2010, p. 251.

12 It should be noted that State armed forces may consist of combatants and non-combatants, including personnel assigned to exclusively medical, religious, or civil defence functions, and that civilians may retain their status although they are integrated, for example, into military aircraft crews. Consequently, membership in regular armed forces clearly depends on formal rather than functional criteria. See: N. Melzer, 'Keeping the balance between military necessity and humanity. A rafour critiques of the ICRC's interpretive guidance on the notion of direct participation in hostilities', New York University Journal of International Law and Politics, Vol. 42 (2010), p. 844.

1.3 Concerning attacks directed against combatants, Yoram Dinstein rightly notices, that "[t]here are [...] a number of caveats: (i) the attack must be carried out outside neutral territory, (ii) it is not allowed when a ceasefire is in effect, (iii) no prohibited weapons may be used, (iv) no perfidious methods of warfare may be resorted to, ( $v$ ) combatants are not to be attacked once they become hors de combat (by choice (surrendered personnel) or because they are wounded, sick or shipwrecked), and (vi) the attack must not be expected to cause excessive injury to civilians". Y. Dinste in, 'Distinction and loss of civilian protection in international armed conflicts', U.S. Naval War College International Law Studies. International Law and Military Operations (ed. by M.D. Carsten), Vol. 84 (2008), p. 184.

14 S.E. Nah lik, 'Status prawny kombatanta', Sprawy Międzynarodowe, No. 12 (1988), p. 114. 
in military operations; moreover, they are entitled to protection against attacks according to IHL, which entails that a civilian is every person who is classified as non-combatant.

Thus, IHL does not provide a clear and express definition of "a civilian" by determining to whom it refers but rather demonstrates which groups of individuals are excluded from the above category. As an advantage of this approach a separable division is guaranteed according to which an individual is either a combatant or a civilian. One and the same individual may not belong to both categories at the same time or belong to neither of them. ${ }^{15}$

Except for the relatively rare case of a levée en masse, ${ }^{16}$ civilians do not have the right to participate directly in hostilities. ${ }^{17}$ Nevertheless, there are many situations in contemporary armed conflicts where civilians directly participate in hostile operations. In such situations they remain civilians but become lawful targets of attacks for as long as they do so. In other words, civilian immunity from attack is lost only where the person takes an active and direct part in hostilities. ${ }^{18}$ The above does not entail that taking part in fighting guarantees the combatant status. As far as IHL is concerned, an individual may either be a civilian or a combatant but never one and the other at the same time. Accordingly, it should be noted that civilians taking a direct part in hostilities lose the protection of "civilian" status but not the status itself. ${ }^{19}$

The status of a civilian is therefore clear: he or she is entitled to protection in so far as he or she refrains from participation in hostilities. Civilians lose protection

15 See: K. Randzio-Sajkowska, M. Sajkowski, 'Ochrona osób cywilnych w konfliktach zbrojnych' in K. Lankosz (ed.), Międzynarodowe prawo humanitarne konfliktów zbrojnych, Dęblin 2006, p. 98.

${ }^{16}$ Civilians who have the status of levée en masse are the inhabitants of a territory which has not been occupied, who, on the approach of the enemy, spontaneously take up arms to resist the invading troops without having had time to form themselves into regular armed units. The participants in such levée en masse are expected to carry arms openly and to respect the laws and customs of war.

17 K. Dörmann, 'The legal situation of unlawful/unprivileged combatants', International Review of the Red Cross, Vol. 85 (2003), p. 46, http://dx.doi.org/10.1017/S1560775500103529.

1" See: Art. 51 (3) of AP I. See also: J.-M. Henckaerts, L. Doswald-Beck, Customary..., rule 6.

${ }^{19}$ K. Wat ki n, 'Warriors..., p. 11 . Nobuo Hayashi describes this status as "[a] conduct-based ad hoc liability to being made the object of an attack by combatants of an adverse party using lawful means and methods of combat while participating directly in hostilities". N. Hayashi, 'Continuous Attack Liability Without Right or Fact of Direct Participation in Hostilities - the ICRC Interpretative Guidance and Perils of Pseudo-Status' in J. Nowakowska-Małusecka (ed.), Międzynarodowe prawo humanitarne. Antecedencje $i$ wyzwania wspólczesności. International Humanitarian Law. Antecedences and Challenges of the Present Time, Bydgoszcz-Katowice 2010 , p. 60 . A contrary view is taken by Yoram Dinstein, who states that "civilians are not allowed to participate actively in the fighting: if they do they lose their status as civilians". Y. Dinstein, The Conduct of Hostilities under the Law of International Armed Conflict, Cambridge 2004, p. 27. 
against direct attack for the duration of their direct participation in hostilities. In addition, such direct or indirect participation in hostilities may constitute the basis for facing criminal sanctions if such possibility is admitted by the penal laws of a given country. With regard to this aspect "Interpretive Guidance" is comparable to conclusions that might be drawn from the Geneva Convention of 1949 and Additional Protocols of $1977 .{ }^{20}$

In case of non-international armed conflict the concept of a "combatant" does not exist (along with the related notion of a "prisoner of war") $)^{21}$ - conflict occurs between armed forces of a state and dissident armed forces or other organized armed groups. ${ }^{22}$ The term "civilian" still exists (though not defined) as well as protection that such persons may enjoy - according to art. 4 (1) of AP II, ,, [a]ll persons who do not take a direct part or who have ceased to take part in hostilities [...] are entitled to respect for their person [...]. They shall in all circumstances be treated humanely", and according to art. 13 (2) of AP II, ,the civilian population as such, as well as individual civilians, shall not be the object of attack", with the reservation that such protection ceases with the moment and for the duration of direct participation in hostilities. Considering the above, an individual may become a target of attack if and to the extent he is a member of an organized armed group or takes direct part in hostilities. ${ }^{23}$ The concept of "direct participation in hostilities" may be interpreted in a manner corresponding to the meaning it has been given in the context of international conflict whereas doubts may be raised by the membership in "organized armed group" since treaty law lacks applicable provisions to determine such membership.

In the light of "Interpretive Guidance" the notion of "organized armed groups" refers to irregular "armed forces" of a state or non-state party to an armed conflict.

211 P. Grzebyk, 'Pojęcia..., p. 64.

${ }^{21}$ M. Sassòli, L.M. Olson, 'The relationship between international humanitarian and human rights law where it matters: admissible killing and internment of fighters in non-international armed conflicts', International Review of the Red Cross, Vol. 90 (2008), p. 607. Compare: L. Doswald-Beck, 'The right to life in armed conflict. Does international humanitarian law provide all the answers?', International Review of the Red Cross, Vol. 88 (2006), p. 889 ("IHL does not formally recognize the status of combatant in non-international conflicts. This is not due to any altruistic articulation by governments of the need to avoid using force against all persons during such conflicts, but rather because of their insistence that rebels must not in any shape or form benefit from any kind of international recognition [...] On the other hand, it is accepted that there cannot be an unlimited use of force by governments during such conflicts").

22 See: Art. 1 (1) of AP II. Under this provision, to be considered an "organized armed group", a group must have a "responsible command", exercise control over territory, carry out "sustained and concerted military operations" and abide by its obligations under AP II.

2.3 However, Louise Doswald-Beck states that "even fighting members of such groups would be exempt from attack in situations where they presented no threat and could easily be arrested, [like in] the hypothetical case of a rebel in the process of doing his shopping in the supermarket [...]. One basis for this conclusion was that he would be a person not taking a direct part in hostilities at that time". L. Doswald-Beck, "The right to life..., p. 890. 
As such, organized armed groups assume combat function and therefore are involved in the conduct of military operations on behalf of one party to the conflict. As opposed to the membership in regular armed forces, membership in organized armed groups is more functional rather than official and according to "Interpretive Guidance" depends on those individuals only who assume continuous combat function. Like in the case of combatants, members of organized armed groups cease to be civilians when they lose protection against direct attack for the duration of performing combat functions. ${ }^{24}$

Exercise of continuous combat function does not imply entitlement to combatant privilege. It has been expressly underlined in "Interpretive Guidance" that this category rather distinguishes members of the organized fighting forces of a non-State party from civilians who directly participate in hostilities on a merely spontaneous, sporadic or unorganized basis or assume exclusively political, administrative or other non-combat functions (e.g. act as a part of a political wing of a given fighting organization). ${ }^{25}$ Continuous combat function requires lasting integration into an organized armed group acting as the armed forces of a non-State party to an armed conflict. Thus, individuals whose continuous function involves preparation, execution or command of operations amounting to direct participation in hostilities are considered to assume a continuous combat function. ${ }^{26}$

In conclusion, exercise of "continuous combat function" within an armed group creates a status as a result of which an individual may become a target of attack at any time, even when such an individual is not directly involved in any hostilities at that time. ${ }^{27}$ An individual ceases to be a legitimate target of attacks only when he permanently disengages from combat functions - the problem is, however, that it is hard to determine how much time should elapse from laying down arms in order for that individual to be qualified as a civilian. ${ }^{28}$

In contemporary armed conflicts it is not easy to distinguish members of organized armed groups from civilians, regardless their combat functions which are not an easy subject of identification, either. ${ }^{29}$ Moreover, it is worth emphasizing that in the co-called asymmetric warfare, due to a significant disparity in power of one party to a conflict, the opposing party - in an attempt to attain their goals - often resorts to violation of $\mathrm{IHL}$, in particular fails to abide by the principle of distinction and ignores measures that might be helpful in distinguishing themselves from civilians, and further, members of such fighting forces intentionally impersonate

24 See: International Committee of the Red Cross, 'Interpretive Guidance..., pp. 27-36, 70.

25 Ibid., pp. 33-34.

26 Ibid., p. 34.

27 Compare: N. Hayashi, 'Continuous.... p. 57.

24 See: P. Grzebyk, 'Pojęcia...', p. 65.

${ }^{29}$ See: M.S. Wong, 'Targeted killings and the international legal framework With particular reference to the U.S. operation against Osama bin Laden', Chinese Journal of International Law, Vol. 11 (2012), p. 148, http://dx.doi.org/10.1093/chinesejil/jmr052. 
civilians and abuse the enemy's good faith. ${ }^{30}$ Such behaviour of a weaker actor of an asymmetric conflict may be of significant military value since varying openly from civilian population and withdrawing from the method of hiding from the enemy might lead to a defeat. The described conduct, however, is a flagrant breach of IHL rules. It must also be noted that the above tactics may lead to weakening of protection of civilian population since the stronger party to a conflict that observes the international law, faces an extremely difficult task of effective distinguishing combatants/fighting groups of an enemy from civilians. ${ }^{31}$

The specific IHL provisions call for the above problem to be justly solved. Under Art. 50 (1) of AP I, "[i]n case of doubt whether a person is a civilian, that person shall be considered to be a civilian". As Yoram Dinstein highlights, "[this] provision is particularly germane to the issue of direct participation in hostilities. It is imperative to ensure that military units tasked with the mission of winnowing out civilians who engage in hostilities will not treat all civilians as targetable". ${ }^{32}$ Additionally, Art. 50 (3) of AP I stipulates that "[t]he presence within the civilian population of individuals who do not come within the definition of civilians does not deprive the population of its civilian character". Thus, "the presence of civilians directly participating in hostilities among the civilian population does not deprive the population at large of the protection from attack that it is entitled to". ${ }^{33}$

The application of the above-mentioned rules might be problematic on the contemporary battlefield. In circumstances of an asymmetric conflict life and safety of combatants more and more depends on how quickly and effectively an adversary blended in the civilian population is recognized. However, it happens very seldom, indeed that an individual in question is successfully identified as non-civilian, which may lead to a situation when combatants, under the applicable law, should treat a potential adversary as a civilian. The above might cause specific problems when a suicide assassination is involved, the efficacy of which greatly depends on an act of perfidy or betrayal of trust (pretending a civilian by an assassinator and blending in the crowd of civilian population). What aggravates the situation is that doubts concerning the status of an assassinator are usually resolved only when an assassination had already been carried out when any preventive actions are beyond reach. A party to the conflict which duly observes IHL provisions has therefore a limited scope of effective methods of defence against an adversary applying such tactics. Despite the above-mentioned inconvenience, it

30) Compare: T.A. Keck, 'Not All Civilians..., p. 3.

3 As rightly noted by Eric Talbot Jensen, the increasing number of victims among civilian population in contemporary conflicts surely results from the lack of possibility to reliably distinguish who, according to the law, may be a legitimate target of attack and who is protected against such attack. E. Talbot Jensen, 'The ICJ's Uganda Wall. A barrier to the principle of distinction and an entry point for lawfare', Denver Journal of International Law \& Policy, Vol. 35 (2008), p. 243.

${ }^{32}$ Y. Dinstein, 'Distinction..., p. 190.

${ }^{3}$ Ibid. 
should be underlined that "protecting civilians from violence is an important cornerstone of a successful counterinsurgency campaign", ${ }^{34}$ therefore in the foregoing case it is extremely important to rely on intelligence and preventive measures even when it would mean having the armed forces involved in activities typical for law enforcement agencies. ${ }^{35}$

While planning a military operation all necessary precautions should be taken to avoid unjustified suffering. Therefore, while deciding upon planning and attacking a specified target, not only operational capability must be taken into consideration but also binding rules governing the use of force along with IHL regulations and standards. In the light of those regulations, all precautions must be taken to verify ex ante that the targeted object is a legitimate military target and even if it is positively ascertained, the kind and degree of permissible force must be proportionate to danger in order to avoid or minimize incidental losses or harms that might be inflicted on civilians or to the civil property. Once it becomes apparent that losses and harms would be excessive in relation to the concrete and direct military advantage anticipated, those responsible must refrain from launching the attack, or suspend or cancel it, if applicable.

As regards civilians, in practice, all feasible precautions must be taken in determining whether the targeted person is a civilian and, if so, whether he directly participates in hostilities. In case of doubt as to whether a person is a civilian, he must presumed to be a civilian; and in case of doubt as to whether a civilian is directly participating in hostilities, it must be presumed that he is not and, therefore, that he remains protected against direct attack. ${ }^{36}$

\section{Actions Which Constitute Direct Participation in Hostilities}

Under Commentary on the Additional Protocol I of 1977, the notion of "direct participation in hostilities" refers to "acts of war which by their nature or purpose are likely to cause actual harm to the personnel and equipment of the enemy armed forces" ${ }^{37}$ According to the ICRC's "Interpretive Guidance", acts falling within the

34 T.A. Keck, 'Not All Civilians..., p. 138.

${ }^{35}$ For example, as noted by Rupert Smith, the reason for engagement of the British Army in Northern Ireland was to support the police forces (such operation was referred to as military support given to civil authorities). The army, therefore, performed an auxiliary function towards civil authorities. R. Smith, Przydatność sily militarnej. Sztuka wojenna we wspólczesnym swiecie. The Utility of Force: The Art of War in the Modern World, transl. by A. i J. Maziarscy, Warszawa 2010, pp. 13-14, 324.

36 N. Melzer, 'Keeping..., p. 857.

37 Commentary on the Protocol Additional to the Geneva Conventions of 12 August 1949, and Relating to the Protection of Victims of International Armed Conflicts (Protocol I), Article 51, para 1944, at <http://www.icrc.org/ihl.nsf/COM/470-750065?OpenDocument>, 9 September 2012 (hereinafter: Commentary on the AP I). 
scope of direct participation in hostilities (DPH) must meet three cumulative criteria, namely:

1. the threshold of harm;

2. direct causation;

3. the belligerent nexus.

Basically, the above criteria demonstrate balanced proportions between the military necessity and humanitarian reasons - rules of fundamental importance from both treaty and customary international humanitarian law's point of view. In practice, those criteria represent rational guidelines for states trying to solve a question whether a certain act qualifies as direct participation in hostilities.

Ad. 1) In order for an activity to qualify as direct participation in hostilities, the harm likely to result from it must attain a certain threshold. This threshold can be reached either by causing harm of a specifically military nature or by inflicting death, injury, or destruction on persons or objects protected against direct attack. ${ }^{38}$ It should be noted that "the qualification of an act as direct participation does not require the materialization of harm [...] but merely the objective likelihood that the act will result in such harm" ${ }^{39}$ Killing or wounding military personnel as well as acts resulting in damage to military objects would obviously qualify. The threshold of harm requirement could also be reached by acts, which may not immediately result in concrete losses, but adversely affect "the military operations or military capacity of a party to the conflict", including sabotage and other armed or unarmed activities restricting or disturbing deployments, logistics and communications. ${ }^{40}$

In the absence of military harm, civilian activities can still amount to direct participation in hostilities if they are likely to inflict death, injury, or destruction. ${ }^{41}$ In most cases, this "alternative threshold of harm" would become relevant

where a party to the conflict directs its attacks not against legitimate military targets but, for example, specifically against the civilian population or civilian objects. While such attacks would invariably amount to grave violations of IHL or even war crimes, the relevant criterion for their qualification as direct participation in hostilities is not that they are unlawful or criminal, but that they constitute an integral part of armed confrontations occurring between belligerents. ${ }^{.2}$

Thus, if civilian conduct is not likely to result in military harm (although it may adversely affect public security or health, like the building of road blocks or the interruption of water and food supplies), it is not part of the hostilities and cannot be qualified as direct participation in hostilities. ${ }^{+3}$

${ }^{34}$ International Committee of the Red Cross, 'Interpretive Guidance..., p. 47.

iy Ibid.

41) T.A. Keck, 'Not all civilians..., p. 142.

41 International Committee of the Red Cross, 'Interpretive Guidance..., pp. 49-50.

12 N. Melzer, 'Keeping..., p. 861.

43 International Committee of the Red Cross, 'Interpretive Guidance..., p. 50. 
To sum up, in order for civilians to lose their protection against attack, they must either harm the enemy's military operations or capacity, or they must use means and methods of warfare directly against protected persons or objects. ${ }^{44}$

Furthermore, it is worth mentioning that

immunity from direct attack does not preclude the permissibility of the use of force, even on a significant scale, if necessary to prevent the commission of grave crimes. It merely entails that the force used against perpetrators not qualifying as legitimate military targets remains governed by the standards of law enforcement and individual self-defence and not by those of the conduct of hostilities. ${ }^{45}$

Ad. 2) According to the ICRC, there must also be "a direct casual link between a specific act and the harm likely to result either from that act, or from a coordinated military operation of which that act constitutes an integral part".46 Moreover, "[f]or a specific act to qualify as direct rather than indirect participation in hostilities there must be a sufficiently close casual relation between the act and the resulting harm". ${ }^{47}$ Thus, "mere participation in the war effort does not rise to the level of direct participation; the individual's actions must be directly linked to the conduct of hostilities". ${ }^{48}$

It must, therefore, be determined how direct participation in military operations differs from indirect participation, or, in a broader sense, in an armed conflict. According to ICRC the difference is between participation in hostilities and participation in war efforts, which, in a way, is conclusive since only the first of the above cited cases entails temporal suspension of immunity of a civilian.

In the event of conventional warfare conducted between states, fixing a strict boundary between "direct participation in hostilities" and "war efforts" does not seem to pose much of a challenge. Actions of the opponent's army are focused on destroying the adversary's military force in open confrontation; otherwise losses of the opponent will be none. Whereas contribution to war effort could be said to include all activities aiming at increase of military power of a party to the conflict to which a civilian belongs. Such contribution does not directly entail inflicting losses to an opponent. For example, production of hand grenades (or Molotov's cocktails) shall obviously bring increase of military power of a party to the conflict, but as such shall not cause any loss to an enemy - therefore may be classified as contribution to the general war effort. Whereas the use of the foregoing weapons during fights with an opposing party shall result in direct probability of harms and losses which qualifies this act as hostility. ${ }^{49}$

44 N. Melzer, 'Keeping..., p. 862.
45 Ibid., p. 863.
46 International Committee of the Red Cross, 'Interpretive Guidance..., p. 51.
47 Ibid., p. 52 .
44 T.A. Keck, 'Not all civilians..., pp. 128-129.
${ }^{44}$ Compare: M.N. Schmitt, 'The interpretive guidance on the notion of direct participation in hostilities. A critical analysis', Harvard National Security Journal, Vol. 1 (2010), pp. 30 -31; R. Borrmann, 'IKRK-Leitfaden unter Beschuss. Aktueller Stand der Diskussion um die 
In ICRC opinion there must be a sufficiently close causal relation between a specific act and a resulting harm. In addition, it must be expressly stated that a given act is capable of bringing about harm "at one causal step" and the distinction between direct and indirect participation in hostilities must be interpreted as corresponding to that between direct and indirect causation of harm..$^{50}$ Therefore, an individual conduct that merely builds up or maintains the capacity of a party to harm its adversary (e.g. by recruitment and training of militants, providing ideological or financial support) or which otherwise only indirectly causes harm (e.g. purchase or smuggling of weapons used in fights) should be excluded from the concept of "direct participation in hostilities". ${ }^{51}$ Such approach as demonstrated above leads to rather narrow understanding of "direct participation in hostilities", in particular to a conclusion that direct participation refers only to the conduct of military operations and an individual who directly participates in hostilities remains a legitimate target of attacks for only as long as he or she is actually involved in participation.

Ad. 3) According to the "Interpretive Guidance", "in order to amount to direct participation in hostilities, civilian conduct must not only be objectively likely to directly cause the required threshold of harm, but must also be specifically designed to do so in support of a party to an armed conflict and to the detriment of another (belligerent nexus)".52 Consequently, "[a]rmed violence which is not designed to harm a party to an armed conflict, or which is not designed to do so in support of another party, cannot amount to any form of participation in hostilities taking place between these parties" ${ }^{53}$

Importantly, the belligerent nexus should be distinguished from concepts such as subjective intent and hostile intent - these relate to the state of mind of the person concerned, whereas belligerent nexus relates to the objective purpose of the act. ${ }^{54}$ As Trevor Keck rightly notes, "[t] he reasons for participation in an act do not matter unless the individual is unaware of his or her participation. For instance, a driver unaware that he is transporting a bomb would remain protected. Any direct attack would need to take his death into proportionality considerations. Thus, while the reasons for the individual's participation in hostilities do not matter, the person's knowledge of participation does". 55

The belligerent nexus is significant in order to distinguish an individual's participation in the conduct of war from criminal activities or acts of self-defence

Auslegung des Begriffs der direkten Teilnahme an der Kampfhandlungen' in M. Kun - Buczko, M. Przybysz (eds.), Bezpieczeństwo w dobie globalizacji. Prawo i praktyka, Białystok 2011, pp. 239-240.

50 See: International Committee of the Red Cross, 'Interpretive Guidance..., pp. 52-53.

51 Ibid., p. 53.

52 Ibid., p. 58.

5. Ibid., p. 59.

54 Ibid.

55 T.A. Keck, 'Not All Civilians..., p. 143. 
against "marauding soldiers" ${ }^{66}$ For example, the stealing of military equipment for private use may cause the required threshold of harm, but is not specifically designed to support a party to the conflict by harming another. ${ }^{57}$ Similarly, taking advantage of a breakdown of law and order to commit violent crimes would not meet the "belligerent nexus" requirement. Furthermore, civilians defending themselves against unlawful attack or looting by the parties to a conflict do not participate in hostilities by virtue of using force to defend themselves. ${ }^{58}$ It is also important to distinguish direct participation in hostilities from violent forms of civil unrest, the primary purpose of which is to express dissatisfaction with the territorial or detaining authorities. ${ }^{59}$ As regards the use of force by civilians against other civilians, to become part of the conduct of hostilities, the use of force must be specifically designed to support a party to an armed conflict in its military confrontation with another. For example, such direct attacks on civilians may meet the "belligerent nexus" requirement, provided the use of force is motivated by the same political disputes or ethnic hatred that underlie the surrounding armed conflict and where it causes harm of a specific military nature. ${ }^{60}$

Additionally, the ICRC highlights basic distinction between the conduct of hostilities and the exercise of power or authority over persons or territory. Consequently, the infliction of death, injury, or destruction by civilians on persons or objects in their power - within the meaning of IHL - does not, without more, constitute part of the hostilities. Moreover, even the perpetration of war crimes or other violations of IHL outside the conduct of hostilities is excluded from the concept of DPH. Thus, while collective punishment, hostage-taking, and summary execution of persons in physical custody are undoubtedly prohibited by IHL, they are not part of the conduct of hostilities. ${ }^{61}$

\section{Temporary Dimension of Direct Participation in Hostilities}

One of the most controversial issues regarding direct participation in hostilities is how to reasonably determine the time limits of such participation during which a civilian loses protection and may become a legitimate target of attack. According to Art. 51 (3) of AP I, civilians enjoy a general protection against dangers arising from military operations "unless and for such time as they take a direct part in hostilities". Therefore, in each case of participation in hostilities it is absolutely vital to determine when such participation starts and when it ends.

56 Ibid.

57 International Committee of the Red Cross, 'Interpretive Guidance..., pp. 60-61.

5H See: T.A. Keck, 'Not all civilians..., p. 143.

${ }^{59}$ International Committee of the Red Cross, 'Interpretive Guidance..., p. 63.

(x) Ibid.

61 Ibid., pp. 61-62. 
According to the ICRC, the concept of DPH undoubtedly includes the immediate execution phase of a specific act meeting the three requirements of threshold of harm, direct causation and belligerent nexus, but it also includes measures preparatory to the execution of such an act, as well as the deployment to and return from the location of its execution, when they constitute an integral part of such a specific act or operation. ${ }^{62}$ In other words, deployments and preparatory measures do not become independent acts of direct participation that can ad infinitum be preceded by further deployments and preparatory measures, but they are regarded as an integral part of an act or operation, which qualifies as direct participation in hostilities because it meets the three above-mentioned criteria. ${ }^{63}$ For example, the loading of bombs onto an airplane in preparation for an attack on military targets constitutes a preparatory measure for a specific hostile act and, therefore, qualifies as DPH. Similarly, the delivery by a civilian truck driver of ammunition to an active firing position at the front line, equipment, instruction and transport of combatants, or gathering of intelligence - if carried out with a view to the execution of a specific hostile act - would have to be regarded as an integral part of ongoing combat operations and, consequently, as DPH. Conversely, mere transportation of weapons from a factory to a storage place for later use, general recruitment and training of personnel, and financial or political support to armed actors would constitute general preparatory measures qualifying as mere indirect participation. $^{64}$

As regards the cases of deployment and return, if the execution of a specific act of DPH requires prior geographic deployment, such deployment already constitutes an integral part of the act in question. Likewise, as long as the return from the execution of a hostile act remains an integral part of the preceding operation, it constitutes a military withdrawal and should not be confused with surrender or otherwise becoming hors de combat. Thus, both the deployment and return should be carried out as an integral part of a specific act amounting to direct participation in hostilities. Importantly, that determination must be made with utmost care and based on a reasonable evaluation of the prevailing circumstances. ${ }^{65}$

The ICRC also explains the temporary and continuous loss of protection, noting that "[o]nce he ceases to participate, the civilian regains his right to protection [...] and he may no longer be attacked".66 Thus, "civilians lose and regain protection against direct attack in parallel with the intervals of their engagement in direct participation in hostilities". ${ }^{67}$ This phenomenon is referred to as the "revolving door" theory and is strongly contested, as it enables insurgents to exploit the law

62 Ibid., p. 65.

${ }^{63}$ N. Melzer, 'Keeping..., p. 883.

w International Committee of the Red Cross, 'Interpretive Guidance..., pp. 56-67.

65 Ibid., pp. 67-68.

s6 Commentary on the AP I, para 1944.

${ }^{67}$ N. Melzer, 'Keeping...'. pp. 883-884. 
to the detriment of law-abiding parties. ${ }^{68}$ However, in Nils Melzer's opinion, this theory "is [...] necessary for the protection of the civilian population from erroneous or arbitrary attack"69 - its aim is to prevent attacks on civilians who do not, at the time, represent a military threat. ${ }^{70}$

On the other hand, "if an individual becomes a member of an organized armed group (which collectively takes a direct part in hostilities), he would lose civilian protection for as long as that membership lasts" ${ }^{71}$ In other words, they lose protection against direct attack for as long as they assume their continuous combat function. ${ }^{i 2}$ Membership in an organized armed group begins in the moment when a civilian starts de facto to assume a continuous combat function for the group, and lasts until he or she ceases to assume such function. Therefore, the "revolving door" concept starts to operate based on that membership. Such attitude seems to be sensible taking into consideration the principle of equality of parties to an armed conflict. If, in case of members of organized armed groups, loss of protection would be limited only to the duration of direct participation in hostilities, it would provide members of such groups with a significant operational advantage over members of State armed forces (who may fall a target of attack throughout the whole duration of a conflict) thus causing an imbalance which is necessary to be maintained under IHL provisions. Such imbalance would, in turn, encourage members of organized armed groups to operate as "weekend fighters" or "farmers by day, fighters by night". Therefore, in practical terms, members of an organized armed group may be targeted, even when not personally linked to any specific hostile act - simply due to their membership in such a group, and as long as that membership continues. ${ }^{i 3}$

To sum up, a civilian who ceases to directly participate in hostilities and a member of organized armed groups of a non-State party who withdraws from continuous combat function, regain full protection against direct attacks. This does not imply, however, that such individuals cannot face criminal sanctions for violation of domestic and international laws. Comments to "Interpretive Guidance" stress that direct participation in hostilities is neither prohibited by international humanitarian law nor criminalized under the statutes of international criminal tribunals but an individual who directly or indirectly participates in hostilities may be prosecuted for violation of domestic laws such as treason, homicide or destruction of property. ${ }^{74}$

6* See: T.A. Keck, 'Not all civilians..., pp. 149-150.

ay N. Melzer, 'Keeping...', p. 891.

71 See: International Committee of the Red Cross, 'Interpretive Guidance..., p. 70. Compare: T.A. Keck, 'Not all civilians..., p. 151

7 Y. Dinstein, 'Distinction..., p. 190.

72 International Committee of the Red Cross, 'Interpretive Guidance..., p. 71.

73 Y. Dinstein, 'Distinction..., p. 190.

is P. Grzebyk, 'Pojęcia...., p. 71. Compare: Commentary on the AP I, Article 51 (3), para 1944 ("Once he ceases to participate, the civilian [...] may no longer be attacked [...] there is 


\section{Restraints on the Use of Force Against Civilians Directly Participating in Hostilities}

In 1975 Professor Jean Pictet wrote: "If we can put a soldier out of action by capturing him, we should not wound him; if we can obtain the same result by wounding him, we must not kill him. If there are two means to achieve the same military advantage, we must choose the one which causes the lesser evil" ${ }^{75}$ The above obviously is not to be understood as imposing an obligation, during a military operation, on members of armed forces to proceed in a manner corresponding to that of law enforcement agencies for which the use of lethal force should be last resort. It should be noted that

combatants are part of the military potential of the enemy and it is therefore always lawful to attack them for the purpose of weakening that potential. The traditional understanding is that no rule restricts the use of force against combatants only to those circumstances in which they cannot be captured. Within humanitarian law this view has been challenged, citing both the principle of military necessity as a restriction on all violence and the prohibition of treacherous killings. ${ }^{76}$

The ICRC expressly supports a notion of "humanitarisation" of warfare underlying that "the right of belligerents to adopt means of injuring the enemy is not unlimited". "In truth, in order to forbid infliction of unnecessary suffering a number of international conventions have been adopted prohibiting the use of means and weapons of a nature to cause superfluous injury and unnecessary suffering and to conduct warfare in a way which denies the fundamental humanitarian rules. Despite, however, numerous standards which govern the use of prohibited means and methods of warfare, the specific provisions of treaty law do not expressly regulate the kind and degree of force permissible against legitimate targets. In the absence of the above express regulations, the ICRC suggests that the use of force in an armed conflict be determined by the principles of military necessity and humanity, which "underlie and inform the normative framework of IHL, and therefore shape the context in which its rules must be interpreted"i8

With reference to the principle of humanity, the so-called Martens Clause, incorporated in both Additional Protocols of 1977, ${ }^{79}$ must be noted. The contents of the Clause remain a part of a customary IHL. In the light of the aforesaid clause, which reflects the principle of humanity, "[i]n cases not covered by this Protocol or

nothing to prevent the authorities capturing him in the act or arresting him at a later stage").

75 J.S. Pictet, Humanitarian Law and the Protection of War Victims, Leiden 1975, pp. 75-76.

${ }^{76}$ M. Sassòli, L.M. Olson, 'The relationship..., p. 606.

77 See: Art. 22 of GC IV and Art. 35 (1) of AP I.

74 International Committee of the Red Cross, 'Interpretive Guidance..., p. 78.

79 See: Art. 2 of AP I and the preamble of AP II. 
by other international agreements, civilians and combatants remain under the protection and authority of the principles of international law derived from established custom, from the principles of humanity and from the dictates of public conscience".

The principle of military necessity which is one of the key principles of IHL, permits only the use of such measures and force and to such degree, which are not forbidden by the laws of war, that are required to bring about the successful conclusion of a military operation, i.e. partial or complete submission of the enemy in the shortest possible time and with the minimum power exerted (which also refers to sparing the lives of own soldiers). What indirectly follows from this principle is an obligation to take into account the humanitarian considerations which forbid superfluous injuries or unnecessary suffering in order to accomplish justified military purposes. ${ }^{80}$ Therefore, in the context of direct participation in hostilities, the principle of military necessity as well as humanitarian considerations should underlie determination of permissible kind and degree of force to be used in justified military circumstances. ${ }^{81}$

Taking into account the foregoing remarks and conclusions, ICRC underlines that the use of lethal force in the circumstances of warfare must be based on a balance between military necessity and the principle of humanity. Obviously, the considerations of humanity and military necessity must not override the specific provisions of IHL but should rather constitute guiding principles to be referred to by military advocates, commanders and soldiers whenever legal regulations are unclear or imprecise. In other words, in instances where IHL lacks precision or is not fully formulated, interpretation must consider the need to maintain balance between the principles of military necessity and humanity. ${ }^{82}$

Proper interpretation of the above-mentioned balance, at the time when warfare is in progress, neither grants combatants an unlimited licence to kill nor imposes "a legal obligation to capture rather than kill regardless of the circumstances". ${ }^{3}$ Decision as to whether a person being a military target ought to be captured or killed must be based on given circumstances, or measures which are reasonable in the prevailing circumstances. The level of restrictions as regards the use of lethal force may increase with the ability of a party to the conflict to control the area and implement the means of stabilisation. As the ICRC highlights, the restraining function "may become decisive where armed forces operate against selected individuals in situations comparable to peacetime policing", ${ }^{84}$ and such circumstances are likely to occur when a party to the conflict occupies the adversary's territory or

*1) International Committee of the Red Cross, 'Interpretive Guidance..., p. 79.

"1 N. Melzer, 'Keeping..., p. 904. For the sake of clarification, the loss of protection against attacks within the meaning of IHL is not to be deemed as a sanction for criminal activities but a consequence of the military necessity in the conduct of hostilities.

"2 T.A. Keck, 'Not all civilians...', p. 154.

*3. International Committee of the Red Cross, 'Interpretive Guidance..., p. 78.

"s4 Ibid., p. 80. 
in case of an asymmetric conflict, conducting warfare against non-State actors on a territory of a given State. ${ }^{85}$

ICRC attitude towards restrictions on the use of force against civilians directly participating in hostilities seems to be gradually shared by states as epitomised by their practice in the issue in question. At this point it might be worth quoting an excerpt from the Israeli Supreme Court's famous verdict in the so-called Targeted Killings, ${ }^{86}$ when the Court was to examine whether the policy of targeted killings as conducted by the Israeli government against suspected terrorists (recognised by the court as civilians) complied with the law. The Supreme Court's findings in the foregoing matter were as follows:

a civilian taking a direct part in hostilities cannot be attacked at such time as he is doing so, if a less harmful means can be employed [...]. Thus, if a terrorist taking a direct part in hostilities can be arrested, interrogated and tried, those are the means which should be employed [...]. A rule-of-law state employs, to the extent possible, procedures of law and not procedures of force [...]. Arrest, investigation and trial are not means which can always be used [...]. However, it is a possibility which should always be considered. It might actually be particularly practical under the conditions of belligerent occupation, in which the army controls the area in which the operation takes place, and in which arrest, investigation and trial are at times realisable possibilities. ${ }^{87}$

In general, the need to minimise victims among civilians and to impose limits on the use of lethal force is also addressed by the new U.S. counterinsurgency (COIN) doctrine. The U.S. military rewrote its doctrine to respond to the changed military and political realities inherent in counterinsurgency warfare. This document requires that U.S. forces use less force as a means to prevent civilian casualties, and places greater emphasis on the provision of governance, social services and capacity building. ${ }^{88}$ Interestingly, the COIN doctrine applicable in U.S. counterinsurgency operations imposes far greater restrictions on the use of force than in conventional warfare. According to U.S. Counterinsurgency Manual, "[i]n situations where civil security exists, even tenuously, Soldiers and Marines should pursue nonlethal means first, using lethal force only when necessary". ${ }^{89}$ It should

"s As Trevor Keck explains, "restraints on the use of force are not hard and fast, but rather change based on the circumstances - namely the intensity of the conflict, the parties' ability to project power and ultimately, what is reasonable in a given situation". T.A. Keck, 'Not all civilians..., p. 155.

*6 The Public Committee against Torture in Israel v. The Government of Israel, Israeli Supreme Court Sitting as the High Court of Justice, Judgment of 11 December 2005, at <http:// elyon 1.court.gov.il/Files_ENG/02/690/007/A34/02007690.A34.pdf>, 2 December 2012.

ki Ibid., para 40.

nk See: T.A. Keck, 'Not all civilians..., pp. 124, 139.

ny U.S. Dep't of Army/Marine Corps, Counterinsurgency Field Manual 3-24 sec. 7-36 (15 December 2006), at <http://www.fas.org/irp/doddir/army/fm3-24.pdf>, 2 December 2012. 
be noted, however, that the U.S. COIN manual is not a legal document. Rather, it provides guidelines and principles for counterinsurgency operations. Nevertheless, as Trevor Keck pointed out, "the implementation of the COIN doctrine [in Afghanistan] had resulted in significantly narrowing the U.S. rules of engagement (ROE), imposing far tighter restrictions on the use of force"..$^{90}$ The currently applicable rules of engagement (ROE) put an obligation on the American armed forces operating in Afghanistan to apply "capture rather than kill" tactics whenever circumstances allow. Even if in possession of reliable and verified information as to the current hiding place of a member of Taliban forces, who has been identified as a legitimate target of attack, the U.S. military should rather try and capture such belligerent, unless he is likely to pose a grave threat to life and security of American soldiers. $^{91}$

\section{Conclusions}

There is no doubt that the concept of direct participation in hostilities remains highly controversial in contemporary armed conflicts. Owing to the employment in warfare of new technological developments, there are increased possibilities to use lethal force without entering the battlefield which implies that such force does not necessarily require to be activated by a human operator. What is more, in a warfare theatre there is a growing trend among states towards outsourcing of traditional military functions to Private Military and Security Companies in order to enhance the chances for a military success. The most significant challenge, however, arises from the participation of non-State armed groups in contemporary armed conflicts who show no respect for the principle of distinction - members of such groups fail to distinguish themselves from the civilian population by wearing uniforms or their insignia and deliberately intermingle with civilians or use them as human shields counting on a physical barrier which shall prevent an adversary from shooting them. In the light of the foregoing facts, the detailed explanation of the notion of direct participation in hostilities and its adequate implementation remains a significant dilemma. ${ }^{92}$ Therefore, ICRC efforts focused on elaboration of detailed guidelines serving interpretation of the notion of direct participation in hostilities, crowned with the adoption of "Interpretive Guidance" must be seen as useful both for military and civil environ-

90 T.A. Keck, 'Not all civilians..., p. 175.

${ }^{91}$ Ibid. However, Trevor Keck clearly states that "[i]ncreased restrictions on the use of force stemming from the COIN doct rine are likely driven by policy", and not necessarily by IHL or IHRL norms. Ibid., p. 176.

92 See: R. Goodma n, D. Jinks, 'The ICRC Interpretive Guidance on the Notion of Direct Participation in Hostilities under International Humanitarian Law: An Introduction to the Forum', New York University Journal of International Law and Politics, Vol. 42 (2010), p. 637. 
ment, involved in humanitarian aid, maintaining or restoring peace and global security. ${ }^{93}$

It should be underlined that "traditional dual privileged status approach of dividing a population into combatants and civilians is only as effective as the accuracy with which the definition of combatant is established and to the extent there is a clear understanding of when civilians lose the protection of their status by participating in hostilities". 94 Therefore, one of the core assumptions of "Interpretive Guidance" defines that only those civilians who exercise "continuous combat function" within an organized armed group or who are continuously involved in direct participation in hostilities may legally be identified as a legitimate target of attack - presuming, in case of doubt, entitlement to protection. Furthermore, individuals directly participating in hostilities only sporadically are civilians, protected unless engaged in hostilities. In order to determine whether a specific act may be qualified as "direct participation in hostilities", States should apply ICRC criteria that comply with both treaty and customary IHL. To lose legal protection, a civilian must perform an act meeting three criteria: 1) threshold of harm; 2) direct causation; and 3) the belligerent nexus. All the cumulative criteria must be met in order for an individual to lose a status of a person protected against direct attack.

Numerous ambiguities that occur in practice as regards the principle of distinction, as well as the need to enhance protection of civilians and to prevent arbitrary killings, cause us to accept the foregoing restrictive criteria. It is worth remembering that targeting individuals who assume political or other functions unrelated to hostilities within an armed group, thus deserve to be recognized as non-combatants, may be regarded as a violation of IHL, expose armed forces to severe criticism and discredit the military operation..$^{95}$

International humanitarian law provides the fighting parties with basic rules and regulations that allow to effectively accomplish military objectives on the one hand and to avoid superfluous suffering and unnecessary victims both among combatants and non-combatants on the other hand. Therefore, it is of utmost importance to maintain balance between the principle of humane treatment and demands of military necessity. In the event of effective territorial control, armed forces should try to ensure security by applying non-lethal means in the first place. Indeed, it would be a gross violation of the rules of law to resort to the use of lethal force in circumstances when arrest or capture is sufficient and more rational

93 As Nils Melzer highlights, "the ICRC's Interpretive Guidance cannot, and does not purport to, replace the issuing of contextualized rules of engagement or the judgment of the operational commander. Instead, it aims to facilitate the task of those responsible for the planning and conduct of operations by providing useful and coherent concepts and principles based on which the required distinctions and determinations ought to be made". N. Melzer, 'Keeping...', p. 856.

\footnotetext{
'K. Watkin, 'Warriors..., p. 9.

"5 Compare: T.A. Keck, 'Not all civilians..., p. 140.
} 
alternative. ${ }^{96}$ In the conduct of military operation, in particular in case of counterinsurgency measures, States should focus on more cautious use of force making their best to balance the fundamental IHL rules - the principle of humanity and of military necessity which, after all, are not mutually exclusive and may successfully be implemented on the contemporary battlefield.

\section{Abstract}

During an armed conflict there may be a situation when a civilian becomes actively involved in hostilities, and since this is in contradiction with the international humanitarian law of armed conflict. By doing so, such person risks being deprived of protection they otherwise deserve and may become the target of enemy assault. Here, however, appears a problem: since the international humanitarian law does not provide a precise definition of "direct participation in hostilities" and fails to specify what activities may be described as connected with or forming its part. An attempt was made by the International Committee of the Red Cross to provide the above definition in Interpretive Guidance on the Notion of Direct Participation in Hostilities under International Humanitarian Law (published in 2009). Despite numerous critics, the foregoing document should be considered as essential and necessary especially at the time of the "war against terrorism" or in the case of the so-called asymmetric conflicts. By defining three obligatory prerequisites that must be met in order for an event to qualify as "direct participation in hostilities", the International Committee of the Red Cross more clearly specified the case of "direct participation in hostilities", putting an end to free choice of interpretation that may cause death of innocent or neutral persons not involved in warfare actions. Accurate interpretation of the abovereferred notion - which is the core topic of the present article - may contribute to more effective protection of civilians against direct attacks and help enforce respect for their life during an armed conflict.

\section{Marcin Marcinko}

Dr. Marcin Marcinko - Senior Teaching and Research Assistant (Chair of Public International Law, Jagiellonian University); coordinator of the International Humanitarian Law and Human Rights Centre, Jagiellonian University; President of the National Commission for International Humanitarian Law of the International Humanitarian Law Dissemination Centre at the Polish Red Cross Main Board; member of the International Law Association - Polish Group; member of the International Association of Professionals in Humanitarian Assistance and Protection (PHAP); winner of the Stanisław Kutrzeba Competition on the Protection of Human Rights in Europe, scholarship holder of the Max Planck Institute for Comparative Public Law and International Law in Heidelberg (2005-2006), scholarship holder of the Hague Academy of International Law (2006); author of numerous publications relating to the issues of fight against terrorism in international law, the use of force in international relations and issues concerning international humanitarian law of armed conflicts. 